\title{
SERVANT LEADERSHIP: MODEL KEPEMIMPINAN KONTEMPORER KEPALA SEKOLAH
}

\author{
Aneke A. Salam \\ Cecilia Lelly Kewo \\ Fakultas Ekonomi - Universitas Negeri Manado \\ anekesalam@gmail.com \\ lellycecilia_kewo@yahoo.com
}

\begin{abstract}
: this study aim to describe the internalization of the philosophy of servant leadership within the leadership of the principal and implementation of the task in the frame of servant leadership. This research using qualitative methods based on descriptive data that were collected through the natural setting from the subject's point of view and is not bound by the issue of teoretical. This research was carried out at the Vocational secondary school of the Catholic Santa Familia in Tomohon city with the subject is the principal and school personnel as a source of information. Results of the study found that: first, the philosophy contained in Servant leadership turns out to have been adopted and animates the leadership school in Vocational secondary school of the Catholic Santa Familia in Tomohon city; Second, the principal at Vocational secondary school of the Catholic Santa Familia in Tomohon has implemented a contemporary leadership models, namely models of servant leadership are humanist, touches the heart in unity work logic and actions that led to the the creation of the atmosphere of the work.
\end{abstract}

.Keyword: Servant,leadership, principal.

Abstrak: Peneliti ini bertujuan untuk mendeskripsikan: internalisasifilosofi servantleadership dalam kepemimpinan kepala sekolahsertapelaksanaan tugas kepala sekolah dalam bingkai servant leadership. Pendekatan penelitian menggunakan metode kualitatif berdasarkan data deskriptifyang dikumpulkan melalui latar alami (natural setting) dari pemahaman atau sudut pandang subyek terteliti dan tidak terikat oleh isu teoritik.Penelitian ini dilaksanakan di Sekolah Menengah Kejuruan Katolik Santa Familia di KotaTomohon dengan subyek terteliti kepala sekolah dan personil sekolah sebagai sumber informasi. Hasil penelitian menemukan bahwa: pertama,filosofi yang terkandung dalam servant leadership ternyata telah diadopsi dan menjiwai kepemimpinan sekolah di SMK St. Familia Tomohon;kedua, Kepala sekolah di SMK Katolik St. Familia dijumpai telah menerapkan model kepemimpinan kontemporer yaitu model kepemimpinan yang melayani (servant leadership) secara humanis,menyentuh hati dalam kesatuan kerja logika dan tindakan yang berujung pada terciptanya suasana kerja yang menyenangkan..

Kata kunci: Servant, leadership, kepala sekolah.

Pemimpin memiliki peran kunci dalam menjaga kelangsungan organisasi melalui upaya menggerakkan segenap personil sesuai tanggungjawab yang diemban, terlebih ketika diperhadapkan pada kemajuan dan perubahan dewasa ini semakin memposisikan pentingnya pemimpin secara khusus organisasi pendidikan atau kepala sekolah harus berperan aktif meningkatkan kualitas layanan pendidikan. Salah satu model kepemimpinan kontemporer yang bisa diterapkan untuk mendukung terciptanya layanan adalah melalui profil pemimpin yang melayani dengan model kepemimpinan melayani (servant leadership). Servant leadership merupakan model kepemimpinan yang memiliki kesesuaian dengan nilai-nilai pendidikan, oleh karena spirit yang mendasari servant leadership menekankan pada upaya memberdayakan dan 
mengembangkan keberadaan seluruh anggota, pengikut atau orang yang dipimpin.

Servant leadership memiliki unsur yang unik dan membedakan dengan jenis kepemimpinan lainnya sebagaimana yang dikemukakan Kent (2016) bahwa servant leadership, memiliki (1) komponen moral, artinya moral menjadi bagian yang terintegral sebagai identitas pemimpin dan ditransfer atau ditularkan kepada bawahan atau pengikutnya; (2) fokus terhadap layanan kepada pengikut atau bawahan, artinya pemimpin memberi perhatian bagi perbaikan, peningkatan dan pencapaian kinerja pribadi bawahan dan bukan sekedar untuk kepentingan organisasi; (3) perhatian kepada kesuksesan semua stakeholder, artinya pemimpin organisasi memandang bahwa keberhasilan organisasi tak lepas dari segala komponen internal maupun eksternal yang terkait dengan organisasi seperti: karyawan, pelanggan, mitra usaha maupun masyarakat; dan (4) refleksi diri, sebagai upaya menghindari profil pemimpin yang angkuh. Pemimpin yang mengusung model servant leadership memberi keterbukaan untuk segenap anggotanya maupun organisasi yang dipimpinnya berpartisipasi aktif dan kreatif serta membangkitkan motivasi yang besar bagi pegawainya untuk bekerja serta melibatkan hati mereka dalam misi dan tujuan organisasi.

Karakteristik yang menjiwai servant leadership dalam perkembangannya terus mengalami pengembangan dan perkembangan untuk diapliksikan dalam organisasi dengan memfokuskan arah energinya pada pertumbuhan dan pencapaian aspirasi pekerja. Nilai-nilai elemen inti dari servant leadership didasarkan pada nilai kerendahan hati dan menghormati orang lain dengan perhatian yang berfokus pada kepercayaan, penghargaan pada yang lain dan pemberdayaan.

Gerakan revolusi mental dan tuntutan pendidikan di Indonesia yang berupaya membangun pendidikan yang berkarakter unggul serta memiliki integritas, tentunya menjadi hal yang perlu didukung dengan model kepemimpinan seperti servant leadership untuk diterapkan di sekolah. Servant leadership sangat cocok dengan semangat tujuan penyelenggaraan pendidikan untuk diterapkan di sekolah sesuai dengan fungsi dan tujuan pendidikan nasional yang tertuang dalam Undang-Undang Republik
Indonesia Nomor 20 tahun 2003 tentang Sistem Pendidikan Nasional Bab II Pasal 3, dinyatakan bahwa pendidikan nasional berfungsi mengembangkan kemampuan dan membentuk watak serta peradaban bangsa yang bermartabat dalam rangka mencerdaskan kehidupan bangsa, bertujuan untuk berkembangnya potensi peserta didik agar menjadi manusia yang beriman dan bertakwakepada Tuhan Yang MahaEsa, berakhlak mulia, sehat, berilmu, cakap, kreatif, mandiri, dan menjadi warga negara yang berdemokratis serta bertanggungjawab. Artinya, pendidikan terkait erat dengan pembentukan karakter atau keberadaan individu yang sifatnya holistik pada peserta didik maupun tuntutan profesional dari komponen lainnya yang terkait dalam pendidikan, seperti guru, tenaga kependidikanserta kepala sekolah selakupemimpin dalam organisasi sekolah. Servant leadership diharapkan dapat memicu terciptanya iklim dan suasana yang dapat membangun pencapaian kinerja (performance) guru dalam kapasitasnya selaku tenaga pendidik yang dapat memberikan layanan prima bagi para pesera didik.

Penelitian Yenming, dkk. (2012) me-nemukan bahwa servant leadership merupakan gaya kepemimpinan yang lebih efektif karena merefleksikan penggunaan kekuatan terbaik seorang pemimpin melalui gaya melayani, dengan hasil temuan bahwa seorang pemimpin yang 'mendengar' serta 'berempati' dan 'membangun komunitas'(saling memahami dan berbagi) adalah gaya kepemimpinan yang diharapkan para pengikut atau anggota organisasi. Hal tersebut sejalan dengan konsepsi dan filosofi dari servant leadership serta dukungan pernyataan Moeljono (2007) yang menyatakan bahwa "pemimpin masa depan pada akhirnya lebih sebagai inspirator, dirigen dan penjaga keseimbangan organisasi daripada hanya sebagai pengontrol dan penyuruh". Seorang pemimpin tidak hanya berada pada tataran puncak untuk sekedar memerintah atau mengontrol. Oleh karena itu, tulisan ini hendak mendeskripsikan adanya internalisasi filosofi servant leadership dalam kepemimpinan kepala sekolah sertaimplementasi pelaksanaan tugas kepala sekolah dalam bingkai servant leadership pada SMK Katolik St. Familia Tomohon. 


\section{METODE}

Peneliti menggunakan metode penelitian kualitatif sebagai metode yang menguji konteks secara keseluruhan interaksi dengan partisipan serta bergantung pada data-data deskriptif (Gay, 1987). Data dalam penelitian ini dikumpulkan dari latar yang alami (natural setting) sebagai sumber data langsung yangditemukan, kemudian di deskripsikan secara menyeluruh dan utuh. Peneliti berupaya menemukan gejala-gejala maupun peristiwa sosial yang tampak, didasarkan pada pemahaman subyek terteliti (atau sudut pandang subyek penelitian) dan tidak terikat oleh isu teoritik (Bogdan dan Biklen, 1998).

Penelitian ini dilaksanakan di Sekolah Menengah Kejuruan Katolik Santa Familia di KotaTomohon dengan subyek terteliti kepala sekolah dan personil sekolah sebagai sumber informasi. Di mana peneliti sendiri bertindak sebagai instrumen kunci (key instrumen) yang masuk ke latar penelitian dan secara langsung berhubungan dengan informan. Sumber data diambil secara purposif, yaitu digunakan untuk mengarahkan pengumpulan data sesuai dengan kebutuhan melalui seleksi dan pemilihan informan yang benar-benar menguasai informasi dan permasalahan secara mendalam serta dapat dipercaya untuk menjadi sumber data.

Teknik pengumpulan data yang digunakan adalah (1) wawancara secara terstruktur, (2) observasi partisipan, serta (3) studi dokumentasi. Dilanjutkan dengan analisis data sebagai proses mencari dan mengatur secara sistematis transkrip wawancara, catatan lapangan danbahan lainnya yang didapat peneliti. Bogdan dan Biklen (1998) mengemukakan analisis data adalah proses pelacakan dan pengaturan secara sistematik transkrip wawancara, catatan lapangan dan bahan-bahan lain yang dikumpulkan untuk meningkatkan pemahaman terhadap bahan-bahan tersebut agar dapat dipresentasikan semuanya kepada orang lain.

\section{HASIL}

\section{Profil SMK Katolik St. Familia di Tomohon}

SMK Katolik St. Familia terletak di pusat Kota Tomohon yangdidirikan pada tanggal 22 februari 1974, dibawah asuhan Yayasan Joseph-
Tarekat JMJ (Jesus Maria Joseph) dengan nama SKKA Katolik St.Walterus Tomohon. Tahun 1977 berubah menjadi SMKK Katolik St.Walterus Tomohon. Tahun 1981 menjadi SMKK Katolik St. Familia Tomohon. Pada tanggal 2 Februari 1987 memperoleh status disamakan berdasarkan keputusan menteri pendidikan dan kebudayaan No.001/c/Kep/1987 dan tahun 1994 menjadi SMK Katolik St.Familia Tomohon kelompok pariwisata.

Adapun visi SMK Katolik St. Familia adalah "Lembaga Pendidikan Yang Menghayati Nilai-Nilai JMJ Unggul dan Berpihak Pada Kaum Marginal". Sedangkan Misi SMK Katolik St. Familia, meliputi: (1) menghayati nilainilai karakter JMJ (lembaga pendidikan yang tanggap terhadap perkembangan zaman dan kebutuhan masyarakat;lembaga pendidikan yang kreatif: memiliki daya cipta, berani membuat terobosan baru, lebih bermutu dan produktif; lembaga pendidikan yang memiliki tanggungjawab terhadap tugas dan kewajiban serta siap menanggung resiko dalam pelaksanaannya; lembaga pendidikan yang memiliki integritas memberikan pelayanan yang bermutu memancarkan kejujuran, ketulusan dan kewibawaan; lembaga pendidikan yang adil: tahu hak dan kewajiban dan berpihak pada yang benar; lembaga pendidikan yang memiliki keramahtamahan bersikap penuh persaudaraan, akrab satu sama lain, bergaul dan bersahabat dengan semua orang; lembaga pendidikan yang berdasarkan kasih sayang:peduli terhadap sesama; lembaga pendidikan yang memiliki rasa hormat menghargai martabat manusia tanpa memandang suku, agama, ras, adat istiadat, golongan dan status sosial; lembaga pendidikan yang disiplin melaksanakan tanggungjawab sesuai dengan aturan yang berlaku); (2) Menjadi Lembaga Pendidikan JMJ yang Unggul (unggul secara ilmiah/ akademis terutama kurikulum, proses dan metode pembelajaran serta penilaian maupun unggul pendidik dan tenaga kependidikannya dengan memiliki kompetensi (kompetensi pedagogik kepribadian, sosial dan profesional) serta memiliki spiritualitas pendidikan; (3) Menjadi Lembaga Pendidikan JMJ yang Berpihak Kepada Kaum Marginal (Adanya kebijakan bagi kaum marginal untuk mengalami pendidikan di sekolah-sekolah JMJ). 
SMK Katolik St. Familia Tomohon memiliki empat jurusan, yaitu: (1) Akomodasi Perhotelan; (2) Administrasi Perkantoran; (3) Jasa Boga; dan (4) Akuntansi Keuangan. Yang didukung oleh ketersediaan Sumber Daya Manusia, meliputi: 26 orang tenaga profesional guru dan 16 orang tenaga kependidikan.

\section{Internalisasi Filosofi Servant leadership dalam Kepemimpinan Kepala Sekolah}

SMK Katolik St. Familia Tomohon sebagai sekolah yang berbasis religius memberi pengaruh yang kuat terhadap gaya kepemimpinan kepala sekolahnya. Nilai-nilai yayasan JMJ (Jesus Maria Joseph) menjadi fondasi kokoh yang mengarahkan penyelengaraan kegiatan maupun personil dalam lingkungan sekolah.Visi dan misi SMK Katolik St. Familia Tomohon yang memberi perhatian pada dua dimensi, yaitu kualitas akademik dan nilai spiritualitas, menjadi unsur yang turut mempengaruhi tertampilnya profil pemimpin sarat dengan filosofi servant leadership yang mendasari setiap tindakan dalam pelaksanaan tugas selaku kepala sekolah.

Ditemukan fakta bahwa kepala sekolah memiliki kepekaan dan kepedulian yang tinggi terhadap perkembangan dan pengembangan diri personil sekolah dengan kemampuan manajerial maupun akademik bahkan mampu memahami kondisi guru, karyawan dan siswa. Kepala sekolah juga memiliki cara pandang personal dengan memposisikan personil sekolah sebagai unsur penting dan perlu mendapat perhatian untuk diberdayakan, sehingga hal tersebut memicu terbangunnya hubungan yang baik serta memacu semangat altruisme (sifat tidak mementingkan diri sendiri) dari pihak pemimpin.

\section{Pelaksanaan Tugas Kepala Sekolah dalam Bingkai Servant leadership}

Kepala sekolah sebagai pemimpin organisasi sekolah,di SMK Katolik St. Familia dijumpai telah menerapkan model kepemimpinan kontemporer yaitu model kepemimpinan yang melayani (servant leadership) secara humanis melalui pendekatan kekeluargaan dan menerapkan asas keterbukaan dengan merapatkan barisan serta membangun kerja sama segenap personil sekolah dalam pengelolaan organisasi, sehingga mendorong pemberian diri segenap personil meningkatkan kinerja personal dan bermuara pada kinerja sekolah secara utuh.

Kepemimpinan kepala SMK Katolik St. Familia Tomohon diterapkan tanpa sekat pembeda yang tak menuntut perlakuan spesial (seperti: hak istimewa untuk dilayani), dikarenakan kepala sekolah berupaya membangun profil pemimpin dengan pendekatan personal yang interaktif dan terbuka, serta senantiasa berbagi pengalaman kehidupan profesional selaku pendidik dari segi keilmuan untuk memotivasi dan meningkatkan spirit dalam menjalankan tugas kependidikan.

Kepala sekolah selalu terbuka dan siap sedia melayani untuk memberi petunjuk, dengan adanya interaksi komunikatif yang dibangun secara berkelanjutan terhadap pihak guru (secara kolektif maupun personal). Kepala sekolah selalu siap sedia mengulurkan tangan memberi pertolongan terhadap persoalan yang dialami oleh personil sekolah terkait dengan kegiatan pembelajaran dan peningkatan pengembangan profesionalitas guru maupun tenaga kependidikan (bahkan bagi para pegawai). Kepala SMK Katolik St. Familia Tomohon memandang tugasnya sebagai tugas tambahan disamping statusnya sebagai guru dengan tampil berwibawa sebagai pemimpin selaku edukator, manajer, administrator, supervisor, leader yang berintegritas, inovator, dan motivator.

Kepala SMK Katolik St. Familia Tomohon, sesungguhnya berhasil membawa iklim yang menyenangkan di sekolah yang dirasakan segenap guru, tenaga kependidikan, para pegawai, bahkan para peserta didik. Kepala sekolah menjadi teladan dan sangat dikagumi oleh para peserta didik maupun guru-guru. Sikap menghargai, ramah, santun serta komunikatif kepada siapapun menjadi salah satu ciri istimewa sang pemimpin yang berujung pada terciptanya suasana kekeluargaan yang menghilangkan sisi kekakuan.

Kepala sekolah selaku pemimpin tampil sebagai pelayan untuk memenuhi kebutuhankebutuhan personil yang menunjang kegiatan profesional di sekolah, guna tercapainya layanan sekolah yang bermutu. Hal tersebut nampak melalui penetapan dan pelaksanaan kebijakankebijakan strategis pemimpin, seperti: mengelola dan menggerakkan personil memacu diri meningkatkan SDM melalui keterbukaan akses 
untuk studi lanjut pada jenjang lebih tinggi dengan merintis jaringan rekomendasi bantuan biaya studi dari pihak yayasan bagi guru, disamping itu adanya agenda tetap tahunan'Program In House Training' serta 're-koleksi' sebagai program pengembangan internal karakter spiritual serta kemampuan profesional segenap personil (pekerja) di sekolah.

Kepemimpinannya Kepala SMK Katolik St. Familia Tomohon berhasil menerapkan atributatribut servant leadership yang dinampakkan secara nyata dalam setiap tindakannya, dimana menjadi pemimpin bukan dengan figur yang main perintah tetapi memegang prinsip bergerak dan bermitra bersama mencapai tujuan, selalu bertindak interaktif-komunikatif-terbuka, serta memiliki integritas yang diteladani, berkemampuan memberdayakan tiap personil sekolah dengan memberi ruang mengikuti pelatihan ataupun penataran bahkan peningkatan jenjang pendidikan, serta memiliki empati tinggidengan kepedulian memberi penghargaan terhadap tiap pencapaian personil sekolah.

Kepala sekolah menerapkan pola keterbukaan dan memberi kesempatan kepada tiap personil sekolah memberdayakan dan diberdayakan guna peningkatan kemampuan profesional personil sekolah dan mencapai tujuan sekolah secara bersama dengan membangun familiaritas hubungan kekeluargaan.

\section{PEMBAHASAN}

\section{Filosofi Servant leadership dalam Kepemimpinan: Kepala Sekolah}

Kepala sekolah selaku pemimpin organisasi pendidikan memiliki posisi yang signifikan bagi kelangsungan atau keberhasilan sekolah dalam memberikan layanan yang bermutu terhadap kegiatan pembelajaran. Layanan tersebut diawali dengan pemberian diri pemimpin untuk melayani, oleh karena model kepemimpinan melayani (servant leadership) memiliki slogan menurut Crippen (Yenming, dkk. 2012), yaitu: "yang pertama melayani kemudian memimpin", hal tersebut menunjukkan dasar servant leadership adalah melayani. Kepemimpinan yang melayani merupakan kepemimpinan yang tampak berbeda, sebab servant leadership membalik piramida pemimpin berada di bawah untuk mendukung organisasi dan bertanggungjawab dengan fokus kepada pengikutnya. Sedangkan pandangan kepemimpinan tradisional dengan cara berpikir piramida menunjukkan penempatan pemimpin di puncak dan para pengikut di dasar. Sendjaya dan Sarros (2002) menyatakan "unsur motivasiservant leadership (yaitu melayani) menggambarkan anggapan mendasar yang membedakan konsep dari gagasan kepemimpinan yang lain, dimana anggapan tersebut membentuk "model mental pemimpin hamba yaitu "aku melayani" bukan "saya memimpin". Alasan utama mengapa ada pemimpin melayani bukan untuk memimpin memposisikan secara berbeda, namun pemimpin hamba menjalankan atau bertindak dengan asumsi bahwa "saya adalah pemimpin, karena itu saya melayani daripada "aku adalah pemimpin, karena itu saya memimpin". Model mental yang dikemukakan Sendjaya dan Sarros (2002), sesungguhnya memposisikan pemimpin sebagai pemimpin dengan idealisme filosofi kehadirannya memberi diri memimpin demi pengembangan dan upaya membangun kepentingan orang lain dalam organisasi yang bermuara pada efektivitas kerja dan pencapaian tujuan organisasi.

Filosofi yang terkandung dalam servant leadership ternyata telah terserap dalam kepemimpinan sekolah di SMK St. Familia Tomohon melalui keberadaan kepala sekolah yang menginternalisasikan model kepemimpinan melayani dalam praktek kepemimpinannyadan didasarkan pada loyalitas maupun konsistensi penerapan visi dan misi sekolah yang dilatarbelakangi oleh kentalnya nilai-nilai religius pada SMK Katolik St. Familia Tomohon.

Adapun servant leadership mendasarkan pada nilai kepemimpinan 'seorang pemimpinyang melayani', dengan filosofi yang dibangun oleh Greenleaf pada tahun 1977. Gagasan Greenleaf tentang servant leadership menandai pergeseran paradigma kepemimpinan dari kekuatan berbasis otoritas ke pemberdayaan (Yenming, 2012) yang sarat dengan perhatian kepada anggota organisasi. Russel (2001) menyatakan bahwa berbicara tentang servant leadership memiliki motivasi dasar kepemimpinan, yaitu keinginan melayani. Sendjaya dan Pekerti (2010) hendak menegaskan bahwa filosofi dan tekanan yang menjadi perhatian dalam servant leadership adalah kehambaan dalam kepemimpinan dan memimpin untuk melayani. Kehadiran pemimpin didasari 
kepada keyakinan bahwa organisasi akan efektif dan mencapai tujuannya ketika memfasilitasi terjadinya pertumbuhan, pengembangan pada tiap individu dalam organisasi.

Gagasan dari servant leadership mengarahkan kepada perilaku yang memupuk dan memberi perhatian pada perkembangan individu dalam organisasi melalui menyimak, berempati, bekerja untuk mengurus dan kesadaran untuk mengembangkan para pengikut secara etis dengan memikirkan dan mendorong hubungan antarpribadi yang baik dengan para kolega (Hoy dan Miskel, 2014). Hal tersebut memperlihatkan bahwa pemimpin memberikan perhatian pada aspek humanistik yangberupaya membangun hubungan baik dengan mengembangkan semangat tidak mementingkan diri sendiri.

Servant Leadership yang didasarkan pada filosofi melayani tentunya tidak mengurangi dan menghilangkan kapasitas ataupun kekuatan sang pemimpin, oleh karena kekuatannya ada dibalik pemberian diri untuk melayani. Hal tersebut sejalan dengan ungkapan servant leadership oleh Stone, dkk. (2004) yang meyakini bahwa tujuan organisasi akan dicapai dalam jangka panjang dengan memfasilitasi pertumbuhan, pengembangan dan kesejahteraan dari individuindividu yang mem-bentuk organisasi.

\section{Pelaksanaan Tugas Kepala Sekolah dalam Bingkai Servant leadership: Kepala Sekolah sebagai Servant Leader}

Servantleadership saratdengan esensifilosofi pendidikan serta menjawab harapan kontemporer di era post-modernisme terlebih dikarenakan bersinggungan dengan semangat pendidikan asih, asah, asuh.Kepala Sekolah di SMK Katolik St.Familia telah mengimplementasikan atributatribut servant leadershipdalam pelaksanaan tugas dan tangung jawabnya selaku pemimpin didasarkan pada prinsip bergerak dan bermitra bersama mencapai tujuan, selalu bertindak interaktif-komunikatif-terbuka, berintegritas dan berkemampuan memberdayakan tiap personil sekolah serta memiliki empati tinggi dengan kepedulian memberi penghargaan terhadap tiap pencapaian personil sekolah.

Russel dan Stone (2002) mengidentifikasikan secara fungsional dan menyertakan atributatribut servant leadership, terdiri dari sembilan fungsi dan masing-masing diikuti oleh atribut yang mendampinginya sebagai penjelasan untuk melengkapi unsur fungsional, meliputi:Visi, merupakan gambaran masa depan ideal serta unik yang terbangun dari perumusan sebagai usaha melihat kebutuhan dan pencapaian masa depan. Pemimpin harus memiliki kemampuan untuk mengkomunikasikan visi bukan sekedar dalam tataran verbal melainkan terintegrasi dalam perilaku yang terlihat dan konsisten; Kejujuran dan integritas, memiliki kesemiripan pengertian dengan bagian yang menyatu dan menggambarkan karakter kepe-mimpinan yang baik berelasi dengan etika dan bermuatan moral. Pemimpin yang jujur dan berintegritas sebagai gambaran pemimpin yang baik dengan kredibilitas (dapat dipercaya, memiliki kebiasaan yang baik, berpegang pada nilai, berkarakter serta kompeten) melahirkan kepercayaan dan komitmen dari pengikutnya; Kepercayaan, merupakan akar dari kepemimpinan sebagai faktor yang signifikan mempengaruhi hubungan pe-mimpin dan anggotanya, sehingga kepemimpinan menjadi efektif dan produktif. Seorang pemimpin harus memberi perhatian pada upaya mendemonstrasikan atau memperlihatkan praktek integritas pribadi dalam tugas organsiasi dan kesetiaannya guna membangun kepercayaan pengikutnya, serta kompetensi berupa pengetahuan dan kemampuan; Pelayanan, merupakan motivasi dasar seorang pemimpin dengan keinginan melayani dan memilih untuk mengenyampingkan kepentingan pribadi. Pemimpin yang melayani memenuhi sumber daya yang dibutuhkan untuk mencapai kesuksesan atau tujuan organisasi dan memberi makna terhadap kerja; Pekerjaan untuk mengurus merupakan bagian mendasar dari pelayanan dan hal tersebut dilakukan olehanggota organisasi maupun pemimpin; Model, merupakan bentuk yang nampak dan diperlihatkan sebagai contoh atau teladan dari seorang pemimpin yang penting dalam servant leadership. Pemimpin yang melayani menarik pengikutnya ke dalam komitmen, dedikasi, kedisiplinan dan keunggulan. Pemimpin diharapkan menunjukkan perilaku yang terlihat (visibilitas) dalam interaksi dengan pengikutnya; Pelopor, memposisikan tuntutan bagi pemimpin untuk menjadi inisiator dan agen perubahan yang luar biasa, berkemampuan mengambil keputusan yang baik, berani mengambil resiko, berani menghadapi tantangan, serta menampilkan keberanian. Pengaruh dan Persuasif dalam ser- 
vant leadership berawal dari semangat kebijaksanaan yang dibagi pemimpin dan mengupayakan pengembangan pemahaman bersama, sehingga para anggota secara sukarela akan mengikuti karena terpengaruh dan teryakinkan; Menghargai yang lain, merupakan tuntutan yang mesti dikerjakan oleh pemimpin untuk secara jelas memperlihatkan penghargaan, nilai dan dorongan serta kepedulian kepada para pengikutnya. Mendengar dan mendorong sebagai bagian yang mesti dilakoni pemimpin dengan esensi peduli dan menjadi berguna bagi orang lain. Pemimpin yang baik adalah pemimpin yang siap "bertanya, memperhatikan, mendengar" serta siap selalu untuk "menguatkan, mengkomunikasikan, menyemangati"; Pemberdayaan, merupakan unsur utama dalam keunggulan kepemimpinan terutama servant leadership. Pemberdayaan menekankan kerja tim dan merefleksikan saling menyayangi dan adanya kesetaraan.Mengajarkandan pendelegasian dalam pemberdayaan memposisikan peran pemimpin pada awalnya untuk belajar dan kemudian mengajarkan prinsip-prinsip serta nilai yang akan membuat para pengikutnya bisa memimpin. Selanjutnya pemimpin yang mendelegasikan menunjukkan suatu wujud berbagi tanggung jawab dengan esensi menyediakan kesempatan bagi para pengikutnya agar mereka dapat melakukan yang terbaik, disamping itu pendelegasian juga menunjuk pada tindak berbagi otoritas, namun tak melepaskan eksitensinya seorang pemimpin.

Hoy dan Miskel (2014) menyatakan bahwa peran kepala sekolah sebagai pemimpin pengabdi (servant leadership) memiliki skor yang tinggi dalam bekerja, oleh karena servant leadership menginspirasi, mempermudah dan mendorong para guru serta menjadi model perilaku yang mendukung mereka dan menentang status quo. Servant leadership sesungguhnya menawarkan potensiaspek perilaku pemimpinyang bermanfaat, oleh karena sekolah merupakan organisasi jasa yang memiliki pengaruh melampaui organisasi itu sendiri. Artinya nilai servant leadership jika diterapkan oleh pemimpin dalam organisasi pendidikan tentunya akan berpotensi positif dalam penerapannya di sekolah oleh kepala sekolah. Dalam latar belakang bisnis melalui hasil penelitian Walumbwa, dkk. (2010) menunjukkan bahwa adanya hubungan positif antara servant leadership dengan keandalan diri karyawan, keadilan prosedural dan OCB (Organizational
Citizenship Behavior), artinya model servant leadership dapat meningkatan kinerja karyawan sebagai anggota organisasi serta mendukung terciptanya iklim yang menyenangkan dalam lingkungan kerja.

Kepemimpinan sejati seperti servant leadership memiliki makna filosofi dengan motivasi dasar adalah membantu orang lain (Yenming, dkk. 2012), tak dapat dilepaskan dari adanya kesadaran bahwa ada kebutuhan manusia untuk membantu dan melayani. Kepala sekolah sebagai pemimpin pendidikan berfungsi mewujudkan hubungan manusiawi (human relation) yang harmonis guna membina dan menggembangkan kerja sama antar personal, agar secara bersama dapat bergerak kearah pencapaian tujuan melalui kesediaan malaksanakan tugas masing-masing.

Pengelolaan pendidikan oleh kepala sekolah dengan menciptakan lingkungan belajar yang kondusif secara berkelanjutan merupakan komitmen dan tuntutan pemenuhan janji sebagai pemimpin pendidikan. Sagala (2010) mengemukakan bahwa kualitaspendidikan yang diterima di sekolah akan menghasilkan kualitas belajar sebagai produk dari keefektifan manajerial kepala sekolah, yang didukung oleh guru maupun staf sekolah lainnya dan dapat menjadi cerminan keefektifan serta keberhasilan sekolah.

Jadi, pada praktiknya kepala sekolah harus memberikan pelayanan yang optimal terhadap kebutuhan tugas guru dan personal sekolah lainnya. Jika kepala sekolah memberikan pelayanan yang memadai kepada seluruh personil sekolah, maka mereka juga akan memberikan pelayanan yang optimal dalam layanan belajar kepada peserta didik oleh guru dan layanan teknis kependidikan oleh tenaga kependidikan yang tepat sasaran sesuai deskripsi kerja dalam organisasi.

Kepala sekolah yang mengaplikasikan servant leadership di sekolah, tentunya menjadi pemimpinyang mampu menyentuh hati dalam kesatuan kerja logika dan tindakan terhadap setiap orang yang berujung pada terciptanya suasana kerja yang menyenangkan. 


\section{KESIMPULAN}

\section{Kesimpulan}

Pada akhirnya dapat disimpulkan sebagai berikut: Pertama, servant leadership bertalian dengan semangatpendidikan asih, asah, asuh dan adanya kandungan nilai religius padavisi misi sekolah berbasis keagamaan (SMK Katolik St. Familia Tomohon) mempengaruhi pola kepemimpinan kepala sekolahnya.Kedua, implementasi servant leadership dilandasi oleh karakteristik pimpinan yang terdorong untuk memberdayakan segenap personil organisasi dengan menerapkan model kepemimpinan secara humanis melalui pendekatan kekeluargaan dan menerapkan asas keterbukaan, membangun kerja sama guna mendorong pemberian diri segenap personil agar meningkatkan kinerja personal dengan memberi layanan yang terbaik.

Kemajuan dan kualitas suatu organisasi pendidikan atau sekolah tak dapat dipisahkan dengan kinerja pemimpin sekolah yang menjalankan tugas kepemimpinannya menggunakan model dan pendekatan kepemimpinan yang tepat sesuai dengan filosofi kependidikan di Indonesia terlebih dalam konteks kekinian. Model kepemimpinan servant leadership direferensikan sebagai salah satu model yang tepat untuk diterapkan di sekolah.

\section{DAFTAR RUJUKAN}

Bogdan, R.C. \& Biklen, S.K. 1998. Qualitatif Research for Education: An Introduction to Theory and Method. Boston: Allyn and Bacon, Inc.

Gay, L.R. 1987. Education Research: Competence for Analysis and Application. Colombus: Merril Publishing Company.

Greenleaf, R.K. 1977. Servant Leadership. A Journey into the Nature of Legitimate Power and Greatness. New York: Paulist Press.

Hoy, W.K., Miskel C.G. 2014. Educational Administration. New York: the MacGra-Hill Companies, Inc.
Kent, M.K. 2016. To Servet FirstTheServant Leadership Journey, (Online), (http://toservefirst. com/definition-of-servant-leadership.html), diakses 24 Maret 2016.

Moeljono, D. 2007. Leadership's Culture: Jawaban atas Tantangan Kepemimpinan di Era Global. Dalam Moeljono, D. \& Sudjatmiko, S. (Ed). Corporate Culture (Challenge to Excellence).

Russell, R.F., and Stone, A.G. 2002. A Review of Servant Leadership Attributes: Developing a Practical Model. Leadership and Organization Development Journal, 23 (3), 145-157.

Sagala, S. 2010. Manajemen Strategik dalam Peningkatan Mutu Pendidikan. Bandung: Alfabeta.

Sendjaya, S., dan Pekerti, A. 2010. Servant Leadership as Antecedent of Trust in Organization. Leadership and Organization Development Journal, 31(7), 643-663.

Sendjaya, S., dan Sarros, J.C. 2002. Servant Leadership: Its Origin, Development, and Application in Organizations. Journal of Leadership and Organization Studies, 9 (2), 5764.

Stone, A.G., Russell, R.F., Patterson, K., 2004. Transformational Versus Servant Leadership: A Difference In Leader Focus. The Leadership and Organization Developmental Journal, 25 (4), 349-361.

Undang-Undang Republik Indonesia No. 20 Tahun 2003 tentang Sistem Pendidikan Nasional

Walumbwa, Hartnell, Oke, A., F.O., Hartnell, C.A., Oke, A. 2010. Servant Leadership, Procedural Justice Climate, Employee Attitudes, and Organizational Citizenship Behavior: A Cross Level Investigation. Journal of Applied Psychology, 95, 517-529.

Yenming, Z., Tzu-Bin L., Fong, F.S. 2012. Servant Leadership: A Preferred Style of School Leadership in Singapore. Chinese Management Studies, 6 (2), 369-383.

Wiyono, B.B. 2007. Metode Penelitian (Pendekatan Kuantitatif, Kualitatif, Dan Action Research). Malang: FIP UM. 